\title{
Oil Spill Response Policies to Bridge the Perception Gap between the Government and the Public: A Social Big Data Analysis
}

\author{
Joungyoon Chun ${ }^{1}{ }^{\circledR}$, Jeong-Hwan $\mathrm{Oh}^{2}$ and Choong-Ki Kim ${ }^{1, *}$ \\ 1 Division for Natural Environment, Water and Land Research Group, Korea Environment Institute (KEI), \\ 370 Sicheong-daero, Sejong 30147, Korea; jychun@kei.re.kr \\ 2 Korea Research Institute of Ships \& Ocean Engineering, 32, Yuseong-daero 1312beon-gil, Yuseong-gu, \\ Daejeon 34103, Korea; jhoh@kriso.re.kr \\ * Correspondence: ckkim@kei.re.kr; Tel.: +82-44-415-7007
}

Received: 2 April 2020; Accepted: 6 May 2020; Published: 9 May 2020

\begin{abstract}
Oil spills cause socioeconomic and ecological damage to the marine environment and local communities. Implementing policies to effectively cope with such incidents is a challenging task due to the negative public perceptions about governmental responses. Using social big data, this study analyzed such negative perceptions in South Korea and the factors influencing them. The findings indicate that the public pays relatively little attention to oil spills but expresses serious concerns about the economic and ecological damage and the health and safety of volunteers and local residents. To improve public perception of oil spills, response strategies should aim to (1) analyze it using social big data to reduce the gap between governmental and public spheres, (2) release timely and accurate information to resolve civil distrust and dissatisfaction, (3) minimize direct damage to local communities and ecosystems affected by oil spills, and (4) reduce the impact on volunteers' and local residents' health and safety. Furthermore, through a multidisciplinary approach that combines social big data analysis methods with marine scientific research, it can contribute to creating a disaster response policy tailored to policy consumers.
\end{abstract}

Keywords: oil spill; public perception; social big data; perception gap; response policy

\section{Introduction}

Oil spills cause extensive damage to marine ecosystems and inflict enormous losses on local communities by interrupting fishing operations and tourism [1]. Several governments are working to prevent oil spill incidents and, failing that, to develop effective strategies for minimizing and recovering from the damage inflicted [2]. Since the Deepwater Horizon (DWH) incident, considered the world's largest industrial oil spill, the regulatory authorities in most countries have improved their oil spill response policies, developed new equipment for controlling marine oil spills, strengthened international cooperation with the cross-border countries [3], and sponsored research and development projects [2]. Furthermore, recent studies on responses to oil spill incidents highlight the importance of linking governmental agencies, private business, volunteers, and local communities to compensate for disasters and restore affected areas [4]. These studies indicate that the public plays an important role in the management of oil spill disasters and marine ecosystems [5].

Despite efforts by the government to manage oil spills and marine incidents, public perception of its responses often remains negative $[1,6]$, thereby impeding its attempts to implement relevant policies. After the DWH incident, for example, oil treatment agents and in situ burning proved more effective than oil skimmers [7]. In Korea, however, these methods are perceived negatively, and their field application is rarely considered. 
Because negative perceptions of oil spill response policies can hinder the implementation of effective response strategies, measures must be taken to shape positive public perceptions of oil spills by providing sufficient information to the public and local communities. The Exxon Valdez oil spill in 1989 first suggested the need to shape public perceptions [8]. Later, after the DWH accident, the U.S. government scheduled two daily press briefings, and the National Incident Commander's office provided daily status reports and continues to provide information about the incident online [9]. At the recent International Oil Spill Conference (IOSC 2017), several researchers emphasized the importance of providing information on the implementation of oil spill response policies, including steps to improve public perceptions.

However, information disclosure alone is hardly enough to improve public perception. Many people, particularly local residents affected by oil spill incidents, have raised fundamental questions about the countermeasures that governments implement [6]. Furthermore, after the DWH accident, many controversies about negative ecological effects and human health problem have been raised in the public sphere [10]. To improve public perception, therefore, we need to identify the root cause of the perceived inadequacies in government policy implementation. To this end, public views on oil spills must first be identified. Additionally, the reasons for the negative perceptions of governmental policies on oil spills must be understood, along with measures to improve these perceptions.

Nevertheless, social science approaches, including public perception analysis, are still an unfamiliar research topic in the field of oil spills as well as response to marine pollution and marine disasters [10]. In particular, studies on people's perceptions and perspectives are analyzed through surveys or interviews of temporarily limited people [11,12]. Therefore, it does not represent the perception of all citizens, and there is a limit to quantitative analysis. This was different from the existing natural science studies such as physics, oceanography, biology, and chemistry based on the results of repeated and quantitative surveys. However, with the development of the Internet and information and communication technology, various traditional media such as newspapers and magazines are being built as database. In addition, with the emergence of social media, such as Twitter and blogs that can connect people, share information, and express opinions, quantitative analysis is also possible in social sciences $[13,14]$. Furthermore, by analyzing people's reactions and emotions to the subject of marine disaster analysis, it is possible to find out what is necessary in the existing marine disaster policy. While there are a number of methodological approaches to understanding and analyzing public perceptions, press releases and social big data are often analyzed using big data techniques such as text mining and original text analysis.

Local studies claim that traditional Korean media generally base their articles on press releases provided by governmental agencies, and, thus, the articles do not necessarily represent the public's perceptions [15]. Public polling has been used to determine public perceptions of oil spills [6]; however, surveys' ability to reveal the linkage between data and causes is limited [16]. In addition, time, cost, and space constraints may bias studies' selection of participants $[17,18]$. Furthermore, it is difficult to determine what media content on oil spills directly impacts public perception. By contrast, social big data, such as blogs, Twitter, and Facebook, are attracting attention as important means of identifying public perceptions and promoting open government policies [19,20]. Indeed, millions of people use social big data daily to post their thoughts on various issues in real time [21]. Thus, analyzing this data may provide insights into crafting customized policies that satisfy the demands of members of the public with negative perceptions.

To this end, this study analyzed social big data to understand public perceptions of oil spills in South Korea. Further, it examined Internet news, including traditional press releases, to understand information provided by government agencies. With these data, the perception gap between governmental agencies and the public was analyzed, and causes of negative public perceptions were determined. The results were used to derive management policies to reduce the gap. 


\section{Materials and Methods}

\subsection{Study Area}

This study focused on the Republic of Korea (hereafter Korea) and its neighboring waters (Figure 1). This area was selected for three reasons. First, Korea has a high rate of marine incident occurrences, including oil spills [22]. From 2002 to 2016, there were, on average, 294 oil spills each year, totaling 24,867 kL of leaked oil during that period (Figure 2a). The Sea Prince incident in 1995 (5,035 kL leakage) and the Hebei Spirit incident in 2007 (12,547 kL leakage) caused serious damage to the local economy and ecosystems. From 2010 to 2016, there were, on average, 1691 marine incidents each year (Figure 2b), resulting in 2704 casualties [23]. The Sewol ferry incident in April 2014, which left 304 people dead or missing, led to serious secondary damage that included a decrease in consumption and a reduction in the number of tourists.

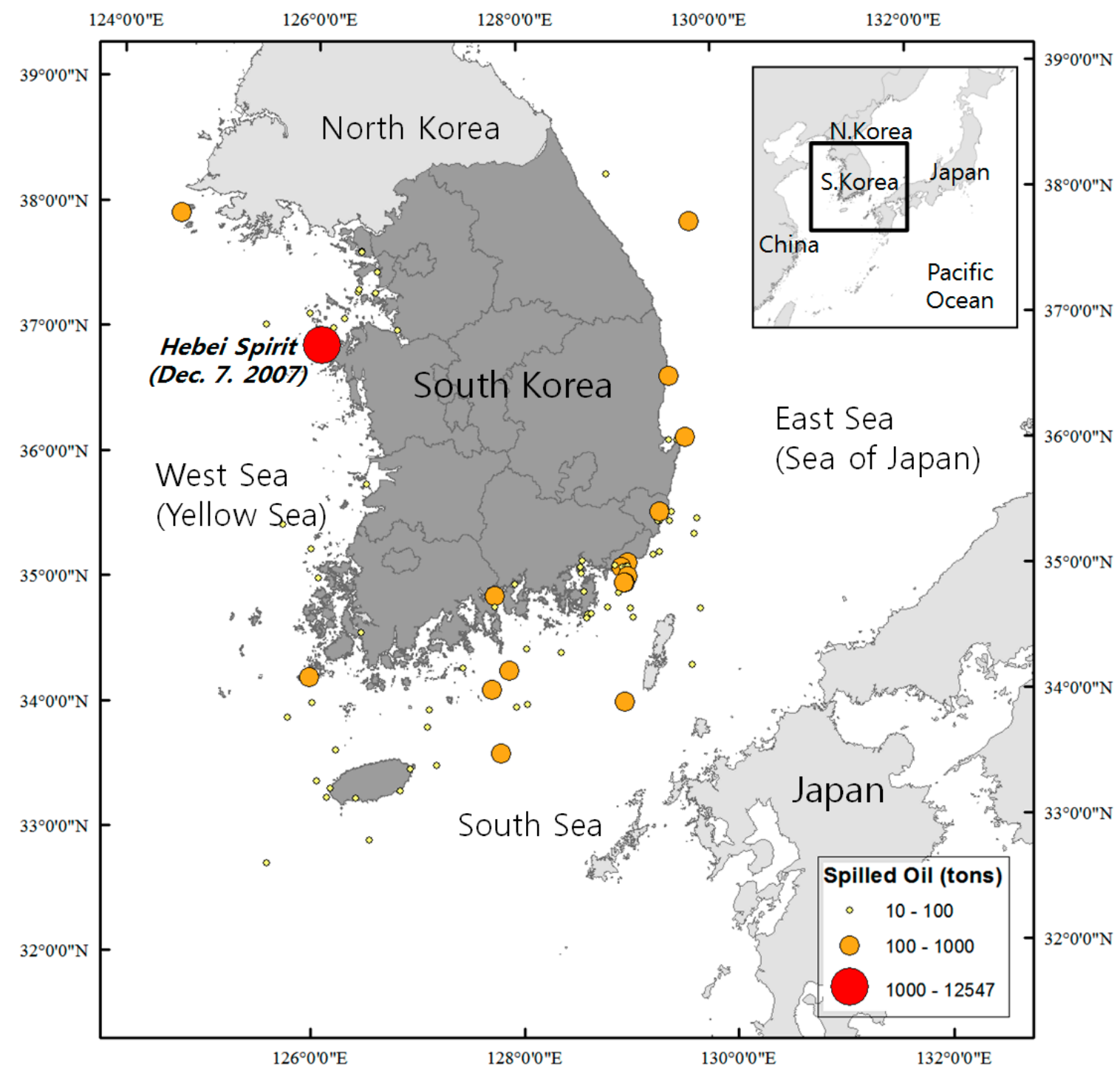

Figure 1. Study area: The circle size represents the amount of leakage (in tons) caused by oil spill incidents from 2002 to 2015. (Data source: [24]). 


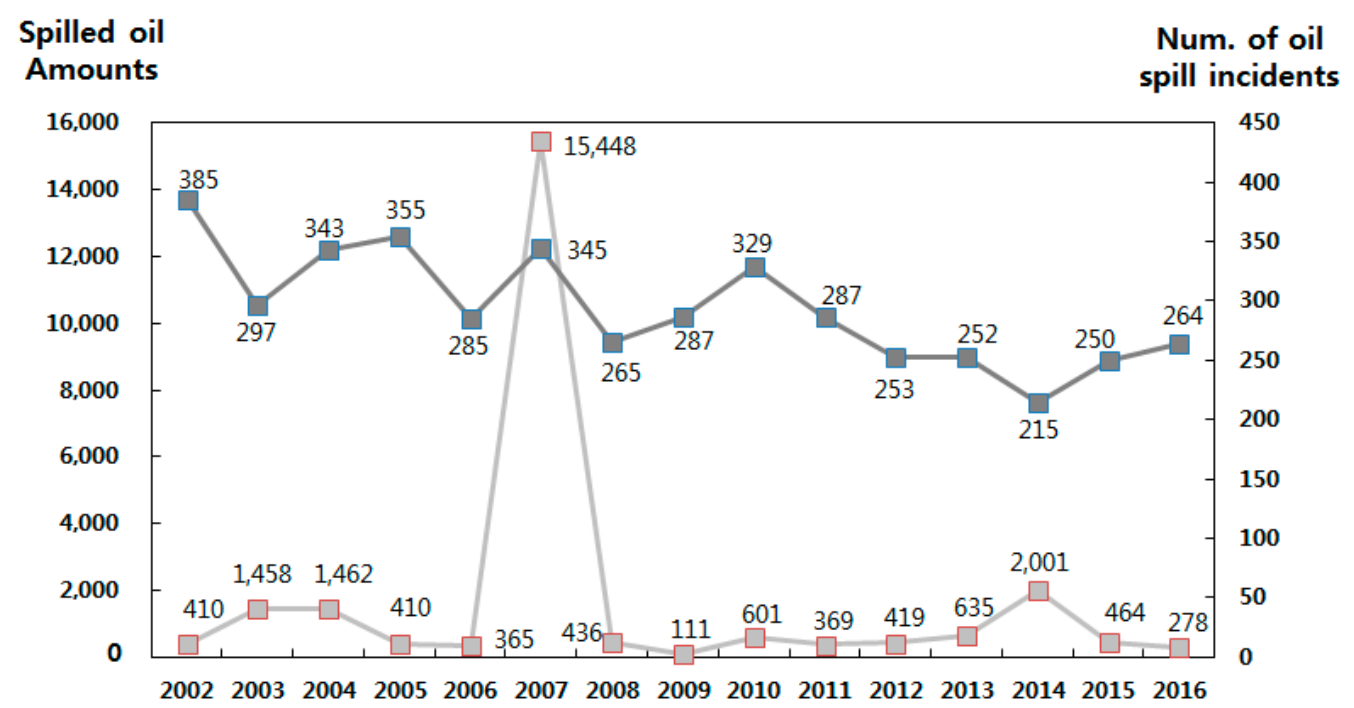

(a)

200220032004200520062007200820092010201120122013201420152016

Num. of
incidents

Num. of human

injuries

(b)

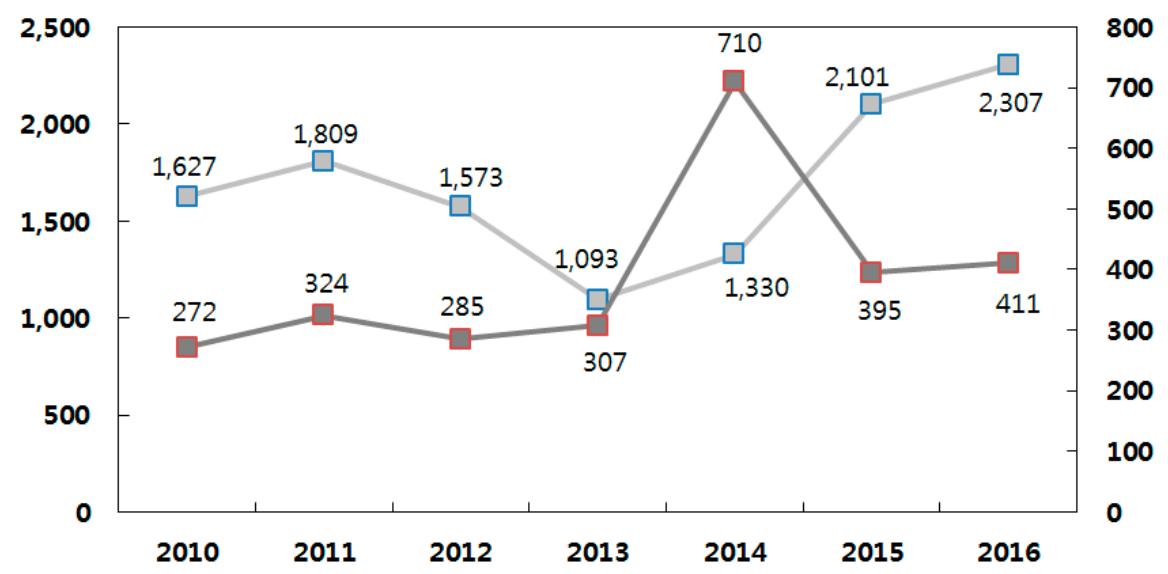

Figure 2. Time series changes in oil spills and marine incidents in Korea: (a) The number of oil spill accidents (right/blue) and the amount of leakage in tons (left/red) over the last 15 years. (b) The number of marine incidents (left/blue) and the number of human injuries (right/red) over the last seven years. (Data source: $[24,25])$.

Second, due to the various economic activities conducted in fishing grounds, fish farms, and the numerous ecological resources, including coastal wetlands and marine endangered species, marine incidents can cause enormous damage. For example, $90 \%$ of the fisheries' licenses issued are in coastal areas, and $92 \%$ of fisheries' households live in coastal areas $[26,27]$. Korea's coastal wetlands (tidal flats) are approximately $2487 \mathrm{~km}^{2}$ [28] and represent $2.5 \%$ of Korea's total land area $\left(100,295.4 \mathrm{~km}^{2}\right)$ [29]. A 2015 coastal wetland ecological survey of the West and South seas identified 401 species of benthos and 65 species of seabirds [30], indicating a high level of biodiversity. Moreover, many species on the International Union for Conservation of Nature (IUCN) Red List of Threatened Species (such as Platalea minor and Egretta eulophotes) and numerous ecologically sensitive resources (such as the nests of migratory birds, seagrass beds, and the Jeju Volcanic Island and Lava Tubes, which is a World Heritage Site) are found in these coastal areas.

Third, social media are actively used in Korea to document public perceptions. In Korea, the rate of Internet use is $92.7 \%$ [31], and the smartphone penetration rate (71.5\%) ranks fourth in the world [32], 
providing excellent conditions for utilizing social big data. There are approximately 22.1 million social network users with mobile phones in Korea [31], indicating that people are actively utilizing social big data in their daily lives and communication. Therefore, social big data may be a strong representation of how Korea's general public perceives marine incidents, including oil spills.

\subsection{Data}

To identify and compare public perceptions of oil spills and relevant information provided by government agencies, the study utilized various big data sources, including social big data and press releases published by newspapers and reported on television (Figure 3). To represent public perceptions, the study used two data sources. First, to determine the changes in keyword use trends, the study used Naver trend search words [33], from 1 January 2007 to 31 October 2016. Naver, the portal with the highest search engine share (77\%) in Korea as of 2015 [34], provides trend data based on search word users' input [33]. Second, to find out public perception, the study collected the contents of four major blogs (Naver blog, Daum blog, Tistory, and Egloos) and Twitter data gathered by Minds Lab [35], from 1 January 2014 to 31 October 2016. Over 2,835,331,462 cases were collected and screened, and 192793 valid cases were used in the data analysis.

\section{Government Sphere}

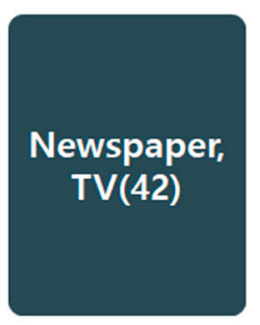

Time: Jan. 1, 2007Oct. 31, 2016 (9y 10m)

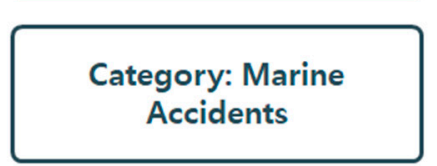

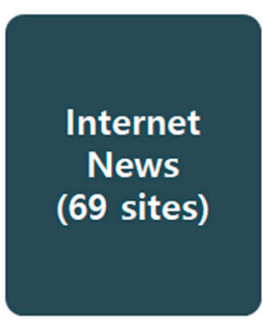

Time: Jan. 1, 2014Oct. 31, 2016 (2y 10m)

Keyword: Oil Spill

\section{Public Sphere}

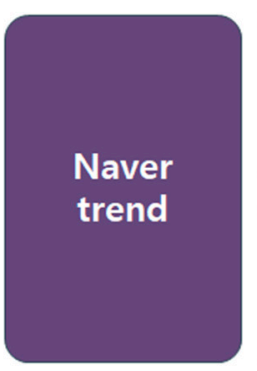

Time: Jan. 1, 2007 -

Oct. 31, 2016 (9y 10m)

Keyword: Oil Spill

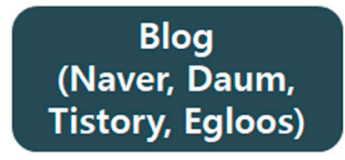

Time: Jan. 1, 2014-Oct. 31, 2016 (2y 10m)

Keyword: Oil Spill

Figure 3. Collected press releases, Internet news, and social big data used to compare the government and public perceptions of oil spills. Traditional media, including newspapers, TV, and Internet news, represent the government perception, while blogs and Twitter represent the public perception.

The study relied on traditional media such as newspaper and TV to understand the government agencies' views. In Korea, government press releases are widely used as news materials because of their reliability and influence [36]. In particular, news outlets prepare articles on large-scale disasters such as oil spills using government-issued press releases. Therefore, newspaper articles and TV commentaries represent the government's views on oil spills. First, the study used the BigKinds Pro service to determine changes in keyword use trends from 1 January 2007 to 31 October 2016. BigKinds, the big data platform of the Korea Press Foundation (KPF), provides 54 media and 60 million Korean newspapers and broadcast articles to the general public as of 2020 [37]. This study analyzes all news reported under BigKinds' accident classification criteria (accidents $\rightarrow$ traffic accidents $\rightarrow$ marine 
accidents). Second, the study used Internet news from 69 sites, gathered by MINDs Lab from 1 January 2014 to 31 October 2016, to understand the government perspective. Internet news is a new media source that started with the emergence of the Internet, which includes homepages created by traditional news and broadcast media, as well as newly opened specialized Internet media. Therefore, the data from this source, similar to the traditional media, can be considered as representing the government's perception. Over 17,271,833 cases were collected and screened, and 61410 valid cases were used in the data analysis.

\subsection{Methods}

The analysis consisted of four stages: Keyword trend analysis, related word analysis, negative predicate analysis, and original text analysis (Figure 4). First, changes in oil spill keyword trends reflected changes in the governmental sector's information and public perceptions over time (January 2007 to October 2016). To analyze governmental response, the study used newspaper and TV articles from KPF's BigKinds Pro. To determine public perception, the study measured changes in the relative frequency of Naver trend search words.
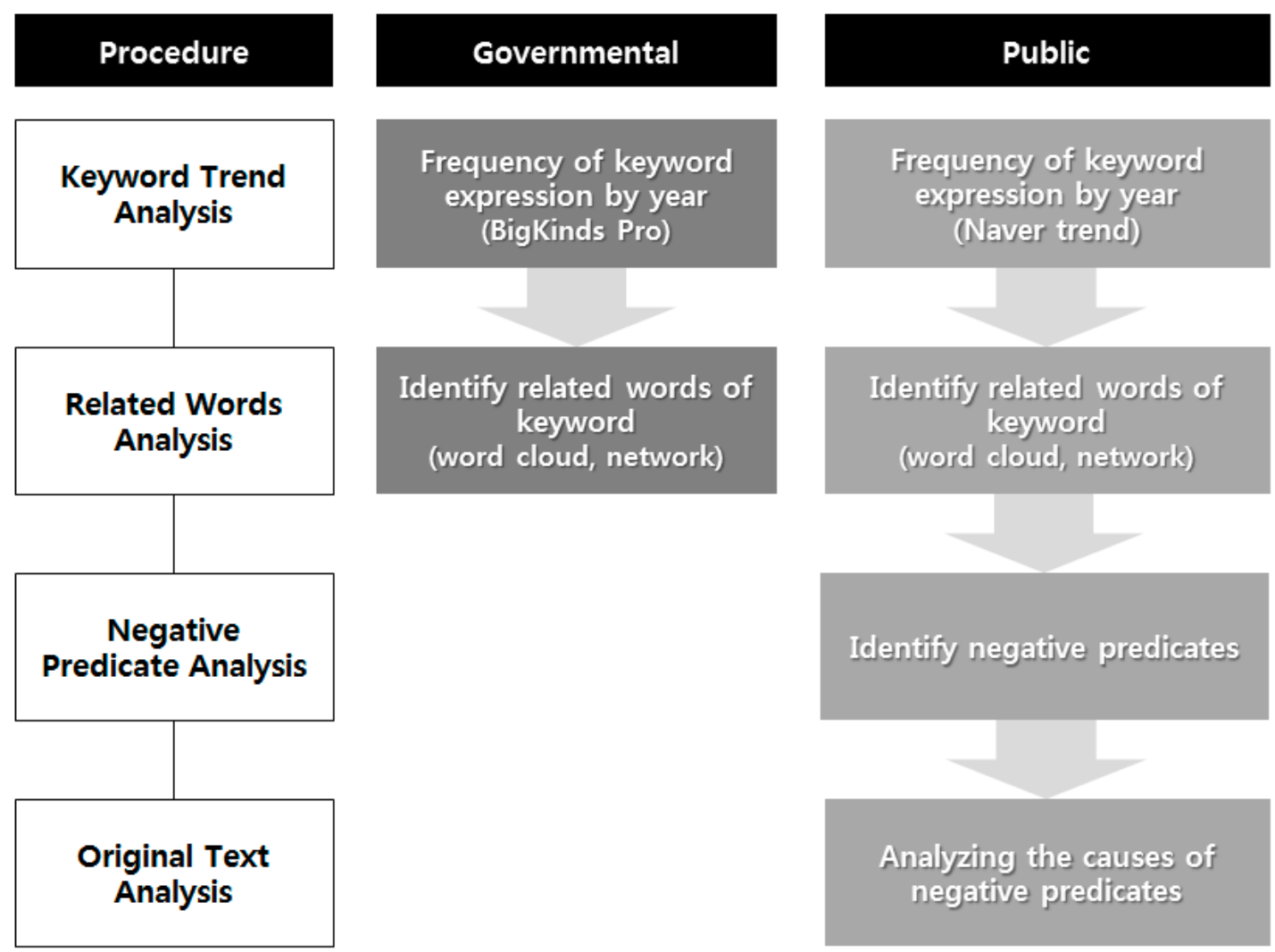

Figure 4. Four-stage process for the analysis of the governmental sector's view and public perceptions: (1) Keyword trend analysis, (2) related word analysis, (3) negative predicate analysis, and (4) original text analysis.

Second, the study conducted related word analysis on the collected big data and social big data articles, to analyze differences between the government view and public perceptions. Related word analysis is a technology for analyzing words associated with the presented keywords, using natural language processing and text-mining technologies. Natural language processing allows computers to understand and manipulate text documents [38], while text mining is a technique used to discover meaningful information from unstructured text [39] and derives patterns, trends, and relationships by applying natural language and document-processing technologies. The study used two data sources 
from Minds Lab: Internet news for the government view and blogs/Twitter for public perceptions. To compare between the two groups, the top 100 related words mentioned by the government and the public were classified into eight categories: Organization, people, place, incident, response, damage, responsibility, and others.

Third, people generally express negative perceptions of a subject or phenomenon through negative predicates, and, thus, this study analyzed the predicates in social big data (Internet news, Twitter, blogs) in terms of how they represented the public's perceptions. Consequently, it is possible to confirm the public's views on oil spills by analyzing people's use of negative predicates: The types of words used and how often they appear. For the analysis, the predicates mentioned more than once in each data source were classified into negative, positive, and others from a response point of view. For example, "prevent" and "prepare" in the responses were classified as positive predicates, and "pollute", "spread", and "blocked" were classified as negative predicates. Next, we compared the proportions of predicates for each category classified by data source.

Fourth, by analyzing the original text containing negative predicates, the study identified the reasons for their use in social big data. By grouping the negative predicates and the causes for the negative descriptions together, the study was able to categorize public perceptions of oil spills and governmental response to them.

\section{Results}

\subsection{Keyword Trend Analysis of Oil Spill Incidents}

The keyword trend analysis showed that mentions of "oil spills" in both the governmental and public spheres increased after oil spill incidents occurred (Figure 5). In terms of number of search queries, with the largest number being $100 \%$, both the government and public spheres revealed relatively high search rates for major oil spills. Mentions of oil spills ranked first and second, respectively, for both the governmental (BigKinds Pro) and public (Naver trend) spheres after the Hebei Spirit incident off the coast of Taean on 7 December 2007 and the Wu Yi San incident on 31 January 2014. On the other hand, there were also differences in the public's and government's use of keywords. First, oil spill-related keywords were cited more often by the government than the public. Second, the difference in the relative frequency of oil spill-related keyword searches was greater in the public than the governmental sphere. While oil spill-related keywords have been consistently mentioned by the government since the Hebei Spirit incident, these keywords have been used by the public only when incidents occur. Third, for some incidents, the search frequency of oil spill-related terms differed between the government and the public. Although the governmental sector used keywords related to oil spills frequently after the Sewol ferry incident (16 April 2014), the public used these keywords less frequently at the time.

\subsection{Related Word Analysis}

The second phase of the study compared the information provided by the governmental sector (Internet news) and public perceptions (blogs and Twitter) through a related word analysis. Figure 6 shows the classification of the top 100 related words that are frequently mentioned by government agencies and the public based on keyword type (Figure 6a) and number of mentions by keyword (Figure 6b). Both government and public spheres showed similar concern, in terms of type of keyword and number of keywords, about organizations, people, places, and accidents. Four of the top five most often used keywords were "Yeosu-si (Yeosu city; organization), minister (people), incident site (accidents), and ocean (place)" for the government (Table A1) and "Yeosu-si (Yeosu city; organization), minister (people), Yun Jin-suk (people), and Taean (place)" for the public (Table A1)". 


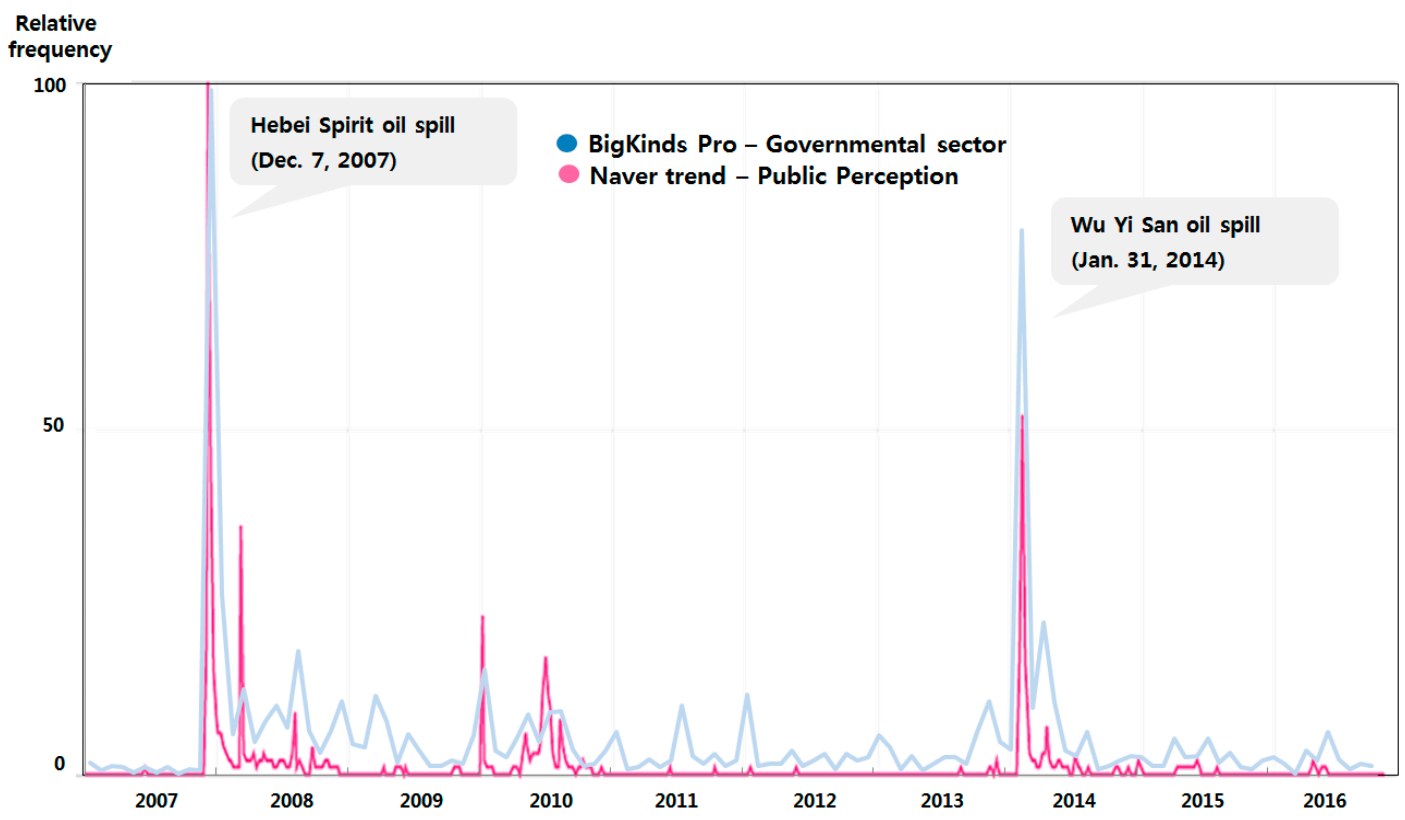

Figure 5. Change in use of the keyword "oil spill" over time [29,31].

However, in terms of response, damage, and responsibilities, both government agencies and the public showed significant differences in terms of keyword types and number of keywords mentioned. Out of the top 100 response-related words, the government (Internet news) accounted for 10, whereas the public sphere (blog and Twitter) had only 3 . The proportion of damage-related words among the top 100 related words showed some differences between the government (Internet news: 12) and public (blog and Twitter: 8) spheres. The total number of public (blog and Twitter: 5185) mentions was about twice the number of government (Internet news: 2622) uses. By contrast, 11 were included in the top 100 (in terms of responsibilities) related words in the public sphere (blog and Twitter), compared to only 3 in the governmental sector (Internet news).

\subsection{Negative Predicate Analysis}

Next, the predicates related to oil spill incidents in Internet news (the government) and blogs/Twitter (the public) were analyzed and categorized into three types: Positive, negative, and others. The analysis results of positive and negative predicates mentioned more than once in each data source are shown in Figure 7. For both the government (Internet news) and the public (Twitter and blogs), negative predicates accounted for a higher share than the positive ones. The difference was that the ratio of positive predicates was higher in the governmental sector than the public sphere, and the ratio of negative predicate was higher in the public sphere than the governmental sector. Out of the positive predicates, only one (minimize) was mentioned in both data sources, whereas seven negative predicates (smell bad, be suspended, be forbidden, be polluted, devastated, suffer, not to know) were common to both data sources (Table 1). In addition, Internet news, on the one hand, and blogs and Twitter, on the other, contained nine positive predicates each. However, both Internet news and blogs/Twitter had more negative than positive predicates. Internet news alone had 12 negative predicates, whereas blogs and Twitter together contained 26 (Table 1). 
(a)

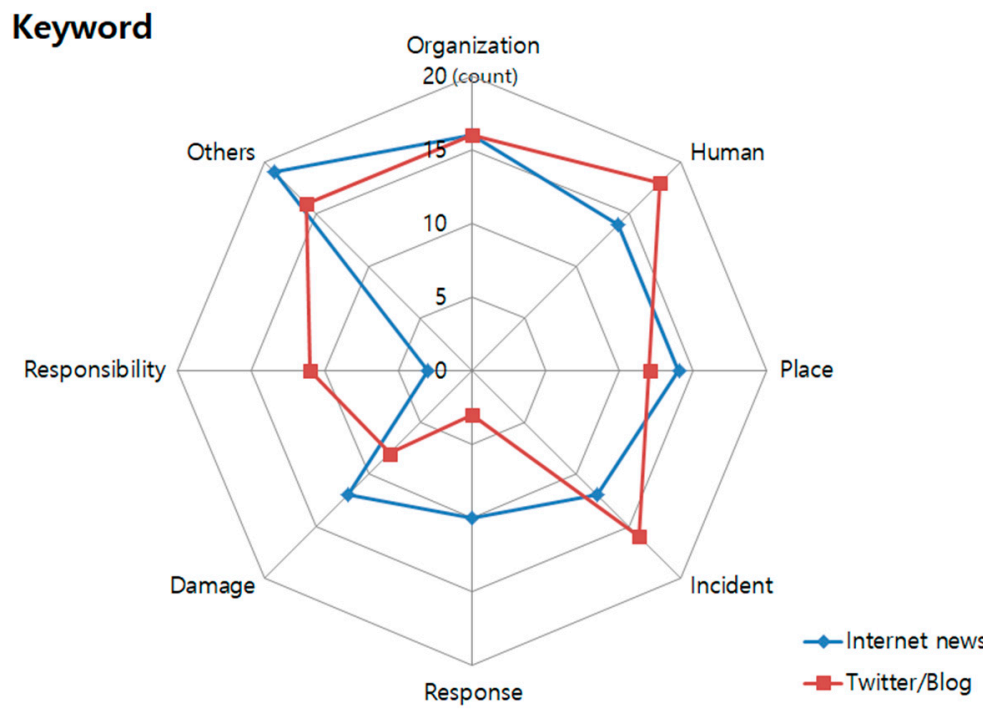

Mention

(b)

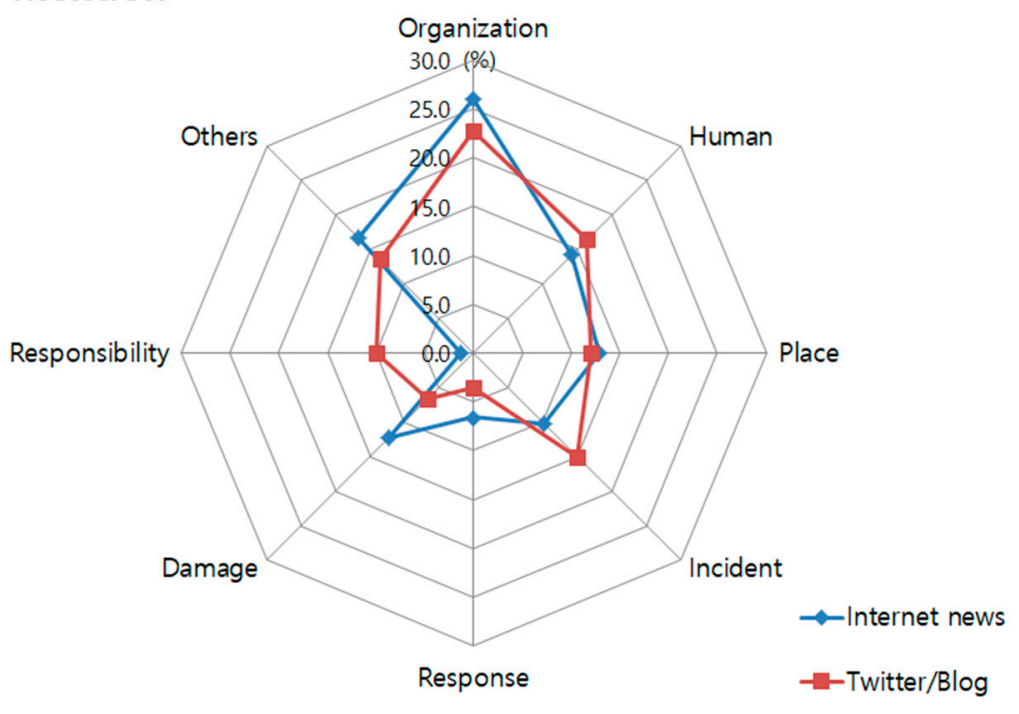

Figure 6. Related word comparison between Internet news and Twitter/blog: (a) Ratio of top 100 related keywords by type; (b) Ratio of top 100 related keyword mentions by keyword type.

\subsection{Original Text Analysis}

The original context of these negative predicates on Twitter and blogs was examined. Most of the negative descriptions of oil spills were related to "environmental pollution" and "local damage", rather than "incident response". In the original texts related to "environmental pollution", "a smiley porpoise (Neophocaena phocaenoides) found off the coast of Taean" was designated as the cause of "suffering" and the "death of a life in the sea" as the cause of being "heartbroken". Further "the sea was polluted and became the sea of death overnight" was related to "tremendous", and "nearby marine ecosystem" was related to "destroyed". In the original texts related to "local damage", "seaweed farming", "oyster farming", and "fish farms" were mentioned in connection with the word "ruined". "Explosion, fire, and loss of life" was related to "scary"; "in the thoughts of elders (damaged region by the oil spill)" was the reason to be "worried"; and "damage to Malipo Beach" connected to "serious". In addition, the relationship between "health damage" and the public's negative perceptions 
was analyzed. "Differences in the carcinogen exposure survey results" and "smell" were related to "serious", and "head" was related to becoming "sick".

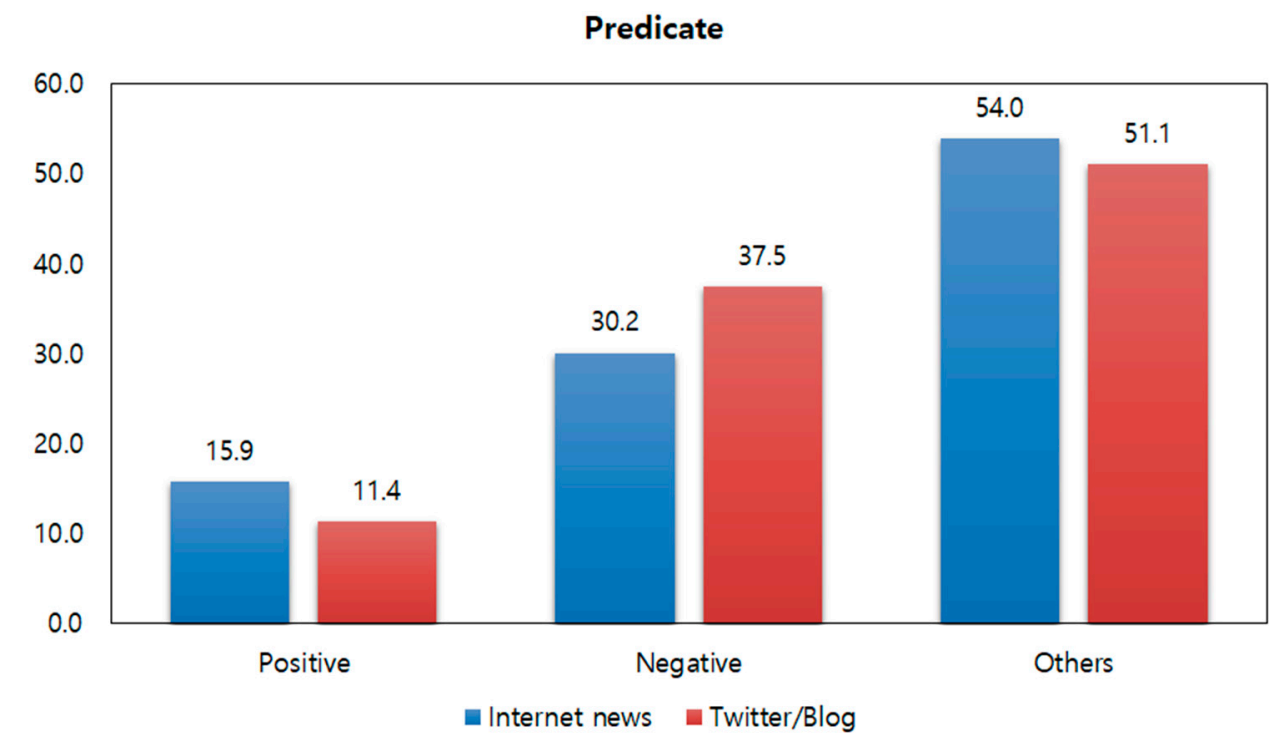

Figure 7. Proportions of positive, negative, and other predicates (etc.) in Internet news (the government) and Twitter/blogs (the public).

Table 1. Predicates commonly mentioned in both data sources and mentioned in only one source (more than twice mentioned).

\begin{tabular}{|c|c|c|c|}
\hline & $\begin{array}{l}\text { Number of Commonly } \\
\text { Mentioned Predicate }\end{array}$ & $\begin{array}{l}\text { Number of Predicate Only } \\
\text { Mentioned in Internet News }\end{array}$ & $\begin{array}{l}\text { Number of Predicate Only } \\
\text { Mentioned in Twitter/Blogs }\end{array}$ \\
\hline Positive & $\begin{array}{c}1 \\
\text { (minimize) }\end{array}$ & $\begin{array}{c}9 \\
\text { (prevent; prepare; } \\
\text { be controlled; introduce; } \\
\text { mobilize; block; investigate; } \\
\text { reduce; sweet) }\end{array}$ & $\begin{array}{l}9 \\
\text { (win; yes; recover; good; handle; } \\
\text { progress; volunteer; guard; settle) }\end{array}$ \\
\hline Negative & $\begin{array}{l}7 \\
\text { (smell bad; be suspended; } \\
\text { be forbidden; } \\
\text { be polluted; devastated; } \\
\text { suffer; not to know) }\end{array}$ & $\begin{array}{l}12 \\
\text { (pollute; stop; spread; go crazy; } \\
\text { be blocked; be ill; blocked; } \\
\text { befall; be damaged; out of } \\
\text { business; burn; poor) }\end{array}$ & $\begin{array}{l}26 \\
\text { (unhappy; spread; abandon; } \\
\text { take time; tremendous; disappear; } \\
\text { tighten; burn; severe; inflict; } \\
\text { change; pain; demolish; lose; } \\
\text { scary; forget; commit; lose out; } \\
\text { ruin; strange; die; collide; violate; } \\
\text { collide; get exposed; fire) }\end{array}$ \\
\hline
\end{tabular}

\section{Discussion}

\subsection{Public Perceptions of Oil Spills and Their Impact on Policy Implementation}

In order to respond urgently to oil spills, which can cause serious damage to the ecosystem, society, and the economy in a short time, stakeholders, including the general public, must be well aware of oil spill incidents, and actively cooperate with the government's incident response process. However, the results of this study show that the public was more concerned about the incident itself and in attributing responsibility than over the response to the incident. Many of the public's most-often used keywords (blog and Twitter) referred to an incident's location, including "Yeosu", "Taean", and "Busan". More keywords related to the investigation into the causes and punishment appeared on blogs and Twitter than in Internet news. For example, "Samsung", the party responsible for the Hebei 
Spirit incident, was not included in the top 100 words in Internet news; however, on Twitter and blogs, "Samsung" and "Samsung Heavy Industries" ranked seventh and 25th, respectively.

This provides implications from two perspectives. Irrespective of how important and urgent the incident response is at an incident response agency, the general public may not take it seriously. On the contrary, if the public perceives that appropriate punishment for the incident is not meted out, negative public opinion can build up. For active public participation in the incident response process, the popular perceptions of oil spill incidents need to change.

The result of the study shows that the public is less concerned about oil spills than the government. In this study, words related to oil spill response, such as control work, countermeasures, support, handing, safety, prevention, response, investigation, work, and situation were highly ranked in the top 100 most-often mentioned keywords in the government sector (Table A1). The public sphere, however, contained only three response-related keywords, such as prevention, obstruct, and volunteer (Table A1). The relatively high government interest in oil spills is the fallout of two major oil spills, the 1995 Sea Prince and the 2007 Hebei Spirit incidents. At the time, the coastal ecosystem in Korea was destroyed, with serious damage to property and fisheries. After these oil spills, government policy recognized the importance of preparedness and effective response to oil spills. On the other hand, the public perceives oil spills as isolated events that do not merit continuous attention. Thus, while oil spills stand out as public political issues immediately after they occur, they are not maintained on the policy agenda in the long term.

This suggests that oil spills have a special significance given that natural disasters caused by such temporary events continue to attract public attention and become important policy issues. Natural disasters such as typhoons, floods, droughts, and heavy snows have had a direct impact on human society, causing considerable damage to life and property over the years. Unlike these natural disasters, however, oil spills are relatively unfamiliar events for most people. Sociologists have mentioned that technical disasters such as oil spills are caused by a combination of highly complex technologies, making them difficult for the general public to understand, so that accidents can be perceived as "normal" [6,40]. Therefore, people have little interest in oil spill incidents and countermeasures unless they are directly affected. This means that, unlike natural disasters, in which the public has a high degree of risk perception, oil spills may be associated with low risk.

However, the public is highly concerned about economic damage. In this study, many damage-related words (e.g., fisheries, compensation, fishermen, pollution damage, damage control committee, nose, fishery products, damage, environment, birds, pollution, and blood) were mentioned in both governmental and public spheres. However, blogs and Twitter often referred to words related to the economic impact of oil spills. This supports previous research findings that the direct impact and compensation of oil spills have a significant impact on the public perceptions to the institutions driving the response policy [6]. Actually, historic oil spills have indicated that commercial fisheries and aquaculture generally suffer damages from such incidents [1,41]. In particular, fishermen's economic activities are conducted on the fishing grounds and fish farms in the coastal areas of Korea, which is the 18th largest producer of seafood in the world [42]. For example, when the Hebei Spirit oil spill occurred in 2007, the area of fish farms in Taean-gun, Chungcheongnam-do, which experienced the most extensive damage, decreased by $53 \%$, from 2273 ha before the accident to 1482 ha seven months after the incident [43]. The damage to fishing and tourism on the Taean coast in the wake of the Hebei Spirit accident was expected to increase, raising public concern not only among local residents such as fishermen but also nationwide. Consequently, more than 1.3 million volunteers from across the country participated in the cleanup [44].

Environmental damage and health-safety problems also impact the public's negative perceptions; people believe that the destruction of the marine environment will eventually indirectly impact their lives. This belief is supported by a number of scientific studies, which have shown that oil spills have a profound impact on seabirds and seaweed [45], and ecosystems require a long time to recover [46,47]. The public is concerned that large-scale oil spills could affect the health and safety of local residents and participants responsible for cleanup. Oil spills have caused various health problems for local 
residents, including post-traumatic stress, asthma, allergies, tumors, depression, anxiety, skin diseases, and precocious puberty, and these effects last for approximately six years after an accident $[48,49]$. Previous studies have reported greater psychological stress from 130 technical disasters, such as oil spills in the United States, than from natural disasters $[1,50]$.

\subsection{Policy Agenda to Improve Public Perception of Oil Spills}

Responding to technical disasters such as oil spills, which have a wide range of environmental, social, and economic impacts, involves the use of advanced technologies and complex processes based on scientific analysis [6]. Therefore, the public needs to logically and scientifically understand the response activities performed by the accident response organizations from a social perspective. Public risk perception is a very important factor in a successful oil spill response strategy [10]. Moreover, responding to oil spills requires the participation and joint action of various stakeholders. Therefore, the government needs to not only upgrade its response techniques but also improve the public perception of oil spill risk.

The following four policies are proposed to improve the public's risk perception of oil spills and awareness of response strategies. First, governments should survey public perceptions of responses to oil spills using social big data and formulate policies based on these perceptions. The anonymity and closed environment of social network services encourage comfortable and open discussion of personal thoughts, interests, and feelings. Thus, it is possible to understand unfiltered public opinions by utilizing social big data, which can help political decision makers and experts develop more concrete resolutions $[10,51]$. Second, the government should implement policies that resolve the public's distrust and dissatisfaction with the government's management of oil spill incidents. The lack of information disseminated by government agencies has exacerbated the negative perceptions of government agencies' oil spill incident countermeasures. This can be decreased by providing timely and appropriate information on oil spill incident responses undertaken by governmental agencies. Therefore, the public needs to be provided with timely and accurate information about the incident and its status, the damage situation, and the government response. Third, the government should implement policies to promote public safety awareness of oil spill incidents. As most oil spill incidents occur due to human factors, enhancing the understanding of all people responsible for these incidents could reduce such occurrences and mitigate their effects. Safety education should classify the problems and appropriate responses based on recent major oil spill incidents and educate the personnel responsible for completing these tasks. Training on response methods for each situation in a concrete, systematic, repetitive, and mandatory manner should be provided routinely.

This study suggests the following damage reduction policies to improve public awareness of the government's response to oil spills. First, countermeasures should be expanded to reduce the impact of oil spill damages on fishermen and their fishing grounds. To do so, updated information on the locations, sizes, production volumes, and values of fishing grounds and fish farms should be periodically provided. When an oil spill occurs, the regions with the most extensive damage must be mapped, and this information should be used to prepare a response. To reduce regional damage, the government should assess expected damage caused by an oil spill in the coastal industrial complex, beaches, and marine protection areas located on the coast and in the ocean, as well as its likely impact on the local economy. For example, after the DWH incident, the United States assessed the damage to properties, including fishery income-generating activities such as maritime transportation and tourism, using a natural resources damage assessment (NRDA), and subsequently used this information to develop and implement a restoration plan [52].

Second, research and policies to reduce the effect of oil spills on ecosystems should be implemented. In the past, the risk assessment study of oil spills for oil spill risk management has been mainly carried out in numerical model-based studies and in predicting spill diffusion modeling [10,53]. However, many studies on the environmental and ecological effects of oil spills have been conducted only focusing on the hazards of specific biological resources and species [54]. These studies have limitations 
in understanding the overall magnitude and impact of oil spills on the environment and ecosystems. The impact of oil spills on the components of the biodiversity of the marine ecosystem and ecosystem services resulting from the interaction of the structure and function of the marine ecosystem must also be evaluated. This assessment process begins by identifying the habitats of species that are particularly vulnerable to oil spills, such as protected areas, seabirds, and group breeding species. The distribution of species vulnerable to oil spills by region and season must also be documented. Using this information, environmental sensitivity maps should be constructed and distributed to response organizations $[55,56]$. Further, it is necessary to assess and categorize the vulnerability of other natural resources, including possible ecological and economic risks over time and space in case of an oil spill, which should be used in building response strategies and actions [57].

Finally, the government should implement policies to reduce health impacts for volunteers participating in oil spill cleanup activities and local residents. In Korea, for example, approximately 1.3 million volunteers participated in relief work after the Hebei Spirit incident [44]. However, volunteers failed to correctly use protective gear and have reported health problems, including allergic rhinitis among children, even 10 years after the incident [49]. Therefore, safety measures must be promoted, and all volunteers must be educated in the use of protective gear. In addition, national and regional agencies must monitor the occurrence of diseases attributable to oil spills among local residents for some time after an incident and implement long-term health management countermeasures.

\subsection{Improving the Preparedness and Response System for Marine Pollution and Marine Disaster by Linking Social Science with Natural Science}

There are a great deal of research and case studies dealing with the scientific and technical aspects of oil spills in the process of oil spill risk management and response [10]. For about 40 years, from 1974 to 2015 , the majority (over $80 \%$ ) of global oil spill research was about biological, chemical, physical, and engineering studies based on natural science approaches $[58,59]$. The development of response technology and equipment, and the government's policy implementation are not much different from academic research. In the United States, Canada, and Europe, many preparedness and response technology development projects are being promoted, such as environmental impacts of oil dispersants, effects of spilled oil on marine ecosystem and marine biodiversity, fate and potential impact of oil spill in poorly understood areas such as the Arctic and water column, and tracking of spilled oil using state-of-the-art remote sensing technologies such as hyperspectral sensor and unmanned aerial vehicle (UAV) $[2,3,60,61]$. In Korea, the national research and development project invested in marine pollution control for 2015-2020 was focused on the technology and equipment development, including the response equipment, identification of oil fingerprints, and the development of a decision support system $[59,61]$.

However, the response cases of DWH (2010) and Hebei Spirit (2007) incidents, the massive oil spills and marine disasters in the 2000s, remind us that social science aspects such as information disclosure and public perception should also be considered in response policy of marine disaster $[4,52,61]$. In particular, the social science approach to marine disasters is necessary in the following two aspects. First, active participation of the private sector is necessary to determine the rational response method. As revealed in the DWH incident, dispersant spraying and new response methods such as in situ burning and bioremediation agents are more effective than traditional mechanical cleanup [7], and they can be rational response methods that reduce the overall damage. However, technical disasters such as oil spills are difficult for the general public to estimate the actual level of damage [62], and there is a lack of understanding of complex accident response technologies. In addition, people are stressed in the event of a disaster and lack of circumstance understanding [10], so if they are buried in the opinions and biased information of some stakeholders, they can hinder rational response countermeasures.

Second, large-scale oil spill incidents affect not only the ecosystem and the environment, but also the community, economy, and public health [43,57,63-65]. Natural disasters, such as typhoons and tsunamis that cause large-scale marine disasters, and marine accidents, which are caused by human error, 
are also similar. The massive tsunami that coincided with the 2011 Tōhoku earthquake and tsunami overlapped with the explosion of the Fukushima nuclear power plant, causing fishing, public health, and social issues in Japan as well as in neighboring countries. These massive environmental, social, and economic damages have a huge impact on the public perception of marine disasters, which makes it more difficult to respond to them. Huang et al. [66] mentioned that the Fukushima nuclear accident had a negative impact on the risk perception among residents around nuclear power plants in China. The grounding and collision of ships belonging to a technical disaster also have an environmental, economic, and social impact. The sinking of the Sewol ferry in April 2014 in Korea sparked public distrust of the operation of the passenger ship and the response system to the incident, which led to a slump in the tourism industry and induced a judgment issue against the regime responsible for the accident.

Therefore, it is possible to establish an effective response system against marine disasters by considering the existing natural science aspects and social science aspects such as people's perception and participation. The social science approach is meaningful in that it provides a means to understand the relationship between people and the risks of technical disasters such as oil spills and marine accidents [10]. In addition, the social science approach can analyze what is needed from the perspective of the people who are policy consumers, so it can identify the missing parts of existing marine science research and disaster response policies. For example, if the social big data-based public perception analysis is used for new policies and technology development tasks for marine disaster response, the limitations of technical and fragmentary research can be overcome, and customized alternatives required by the policy consumer can be drawn.

In the oil spill field, however, public risk awareness and risk communication agenda are treated separately from existing preparedness and response policy development projects [10]. In response to marine accidents, social media channels such as YouTube have been recently established for risk communication [10], but the gap between the public sector and the government is still large. As such, efforts are being made to link social science research with marine policy, but the integration of marine social science into marine policy has yet to overcome the gap between government and public knowledge and awareness, and also requires challenging attempts [67]. In order to derive policy outcomes, it is also necessary to consider how to integrate marine science and sociological research results throughout the plan-do-see process, from policy goal setting to planning, project execution, and policy evaluation. Therefore, it is necessary for government officers to set explicit and achievable policy objectives for managing marine disaster risk and improving response systems. In order to achieve the goal, convergence research and policy should be developed from a multidisciplinary perspective that integrates marine scientific analysis and social science approaches.

\section{Conclusions}

This study analyzed the public perception of oil spills using social big data in Korea, where oil spills have frequently occurred in recent years. This study is significant in that it is the first attempt to analyze the perception gap between government awareness, represented by Internet news, and public awareness, represented by social big data. This study can help government agencies to respond to oil spill incidents by uncovering areas of particular interests to the public. Furthermore, this study provides some considering points to government officers and researchers who make policy alternatives by integrating social science and marine science for responding to marine disasters. However, it has some limitations. Considering the difficulty of obtaining social big data, this study covered only a short analysis period, from January 2014 to October 2016. Moreover, its methodology to identify public perception was limited to related word and negative predicate analyses. As this study only conducted comparisons between the government and the public, it did not consider the perceptions of other stakeholders.

Therefore, we propose a follow-up study along the following lines. To understand how mid- to long-term public perceptions of oil spills change, we will need to use complementary methods such as 
literature analyses and questionnaire surveys to supplement social big data research. Furthermore, the factors that affect risk perception by the public need to be investigated to improve oil spill risk perception. The proposed study should consider the needs of various stakeholders and incorporate their diverse views into an effective oil spill response strategy.

Author Contributions: Conceptualization, J.C. and C.-K.K.; methodology, J.C. and C.-K.K.; software, J.C.; formal analysis, J.C.; investigation, J.C.; resources, J.C.; writing-original draft preparation, J.C. and J.-H.O.; writing-review and editing, C.K. and J.-H.O.; visualization, J.C. and C.-K.K.; supervision, C.-K.K.; project administration, C.-K.K.; funding acquisition, C.-K.K. All authors have read and agreed to the published version of the manuscript.

Funding: This research was supported by the project titled 'Marine Oil Spill Risk Assessment and Development of Response Support System through Big Data Analysis' of the Korea Institute of Marine Science \& Technology promotion, funded by the Korea Coast Guard, grant number 20190439. The article processing charges was funded by the Korea Coast Guard, grant number 20190439. This research was conducted by the Korea Environment Institute.

Acknowledgments: Gowoon Kim helped English translation during this study. Minds Lab helped analyze social big data.

Conflicts of Interest: The authors declare no conflict of interest. The funders had no role in the design of the study; in the collection, analyses, or interpretation of data; in the writing of the manuscript, or in the decision to publish the results.

\section{Appendix A}

Table A1. Top 100 keywords related to "oil spill" (Internet news vs. blogs and Twitter).

\begin{tabular}{|c|c|c|c|c|}
\hline \multicolumn{3}{|c|}{ Internet News (Governmental Sector) } & \multicolumn{2}{|c|}{ Blogs and Twitter (the Public Sphere) } \\
\hline Rank & Keyword & Frequency & Keyword & Frequency \\
\hline 1 & Yeosu-si (Yeosu city) & 1737 & Yeosu-si (Yeosu city) & 3718 \\
\hline 2 & minister & 764 & minister & 2385 \\
\hline 3 & incident site & 692 & Yun Jin-suk & 2319 \\
\hline 4 & sea & 632 & Taean & 1942 \\
\hline 5 & relevance & 624 & (disaster) prevention & 1604 \\
\hline 6 & ocean & 598 & Taean peninsula & 1504 \\
\hline 7 & occurrence & 563 & Samsung & 1419 \\
\hline 8 & fishery & 555 & Taean-gun(Taean county) & 1312 \\
\hline 9 & Caltex & 520 & hole & 1295 \\
\hline 10 & GS Caltex & 513 & Taean oil & 1284 \\
\hline 11 & GS & 507 & Busan Metropolitan City & 1248 \\
\hline 12 & Yun Jin-suk & 483 & Caltex & 1198 \\
\hline 13 & damage compensation & 407 & GS Caltex & 1198 \\
\hline 14 & fishermen & 407 & GS & 1186 \\
\hline 15 & Ministry of Oceans and Fisheries & 398 & sea water & 1128 \\
\hline 16 & incident & 378 & fatal incident & 1081 \\
\hline 17 & Jeollanam-do & 356 & incident site & 1051 \\
\hline 18 & Busan Metropolitan City & 317 & fishery & 1049 \\
\hline 19 & pollution damage & 307 & Ministry of Oceans and Fisheries & 1015 \\
\hline 20 & residents & 286 & incident & 989 \\
\hline 21 & offshore of Yeosu & 273 & It's the same & 977 \\
\hline 22 & damage control committee & 271 & sameness & 977 \\
\hline 23 & controversy & 239 & article & 974 \\
\hline 24 & control work & 225 & victim & 969 \\
\hline 25 & $\begin{array}{l}\text { minister of Ministry of Oceans } \\
\text { and Fisheries Yun Jin-suk }\end{array}$ & 216 & Samsung Heavy Industries & 938 \\
\hline 26 & countermeasures & 212 & industry & 938 \\
\hline 27 & National Assembly & 204 & photo & 909 \\
\hline 28 & $\begin{array}{l}\text { government-ruling party } \\
\text { consultation }\end{array}$ & 200 & event & 907 \\
\hline 29 & support & 198 & $\begin{array}{c}\text { South Regional Headquarters } \\
\text { Korea Coast Guard }\end{array}$ & 887 \\
\hline 30 & minister Yun & 198 & obstruct & 883 \\
\hline
\end{tabular}


Table A1. Cont.

\begin{tabular}{|c|c|c|c|c|}
\hline \multicolumn{3}{|c|}{ Internet News (Governmental Sector) } & \multicolumn{2}{|c|}{ Blogs and Twitter (the Public Sphere) } \\
\hline Rank & Keyword & Frequency & Keyword & Frequency \\
\hline 31 & Wu yi San & 187 & $\begin{array}{c}\text { photo of Yun Jin-suk MOF } \\
\text { minister }\end{array}$ & 880 \\
\hline 32 & adequacy & 174 & substance & 869 \\
\hline 33 & government & 168 & possession & 869 \\
\hline 34 & area & 166 & substantial owner & 868 \\
\hline 35 & $\begin{array}{c}\text { member of the National } \\
\text { Assembly }\end{array}$ & 166 & reason & 867 \\
\hline 36 & Yeosu Coast Guard & 165 & Yeosu side & 865 \\
\hline 37 & inappropriateness & 165 & others & 864 \\
\hline 38 & president & 162 & others & 864 \\
\hline 39 & statement & 159 & punishment & 861 \\
\hline 40 & handling & 159 & adjudicate & 850 \\
\hline 41 & on the sea & 156 & judgment & 847 \\
\hline 42 & on this day & 154 & it's a judge & 847 \\
\hline 43 & this time & 150 & $\begin{array}{c}\text { minister of Ministry of Oceans } \\
\text { and Fisheries }\end{array}$ & 839 \\
\hline 44 & visit & 150 & damage to fishermen & 787 \\
\hline 45 & nose & 149 & $\begin{array}{l}\text { minister of Ministry of Oceans } \\
\text { and Fisheries Yun Jin-suk }\end{array}$ & 731 \\
\hline 46 & safety & 146 & fire & 724 \\
\hline 47 & victim & 141 & bomb terror & 703 \\
\hline 48 & mouth & 137 & slip of the tongue & 693 \\
\hline 49 & oil tank & 137 & Sewol & 684 \\
\hline 50 & Crude Wharf & 136 & vehicle & 682 \\
\hline 51 & oil tanker & 134 & coast & 676 \\
\hline 52 & Saenuri & 134 & tourism & 674 \\
\hline 53 & Saenuri Party & 131 & tourist & 674 \\
\hline 54 & conference & 130 & guiltiness & 669 \\
\hline 55 & commissioner & 127 & suspicion of rebellion & 668 \\
\hline 56 & photo & 127 & Korea & 667 \\
\hline 57 & sea water & 124 & president & 666 \\
\hline 58 & police & 117 & Korean & 662 \\
\hline 59 & people & 113 & large event & 657 \\
\hline 60 & representative & 112 & collapse & 638 \\
\hline 61 & reshuffle & 110 & marine life & 572 \\
\hline 62 & Taean-gun & 109 & building & 556 \\
\hline 63 & freight & 108 & responsibility & 555 \\
\hline 64 & cargo ship & 108 & Jongno-gu & 549 \\
\hline 65 & AI & 108 & auditorium & 545 \\
\hline 66 & prevention & 107 & Sinai peninsula & 544 \\
\hline 67 & Yeosu Industrial Complex & 105 & forgery of evidence & 541 \\
\hline 68 & minister Yun Jin-suk & 104 & Seoul Metropolitan City & 541 \\
\hline 69 & $\begin{array}{c}\text { MOF (Ministry of Oceans and } \\
\text { Fisheries) }\end{array}$ & 103 & $\begin{array}{l}\text { Seoul spy case prosecution } \\
\text { service }\end{array}$ & 540 \\
\hline 70 & Crude 2 Wharf & 103 & prosecution service & 540 \\
\hline 71 & response & 103 & body & 487 \\
\hline 72 & lately & 100 & sea & 483 \\
\hline 73 & oil & 100 & President Roh Moo-hyun & 481 \\
\hline 74 & $\begin{array}{c}\text { Yeosu Federation of Fisheries } \\
\text { Cooperatives }\end{array}$ & 100 & death accident & 443 \\
\hline 75 & fishery products & 100 & residents & 442 \\
\hline 76 & words and actions & 99 & west coast & 423 \\
\hline 77 & problem & 99 & $\begin{array}{l}\text { minister of MOF (Ministry of } \\
\text { Oceans and Fisheries) }\end{array}$ & 400 \\
\hline 78 & Haeundae-gu & 98 & damage & 380 \\
\hline 79 & Nakpo & 97 & attach & 380 \\
\hline 80 & investigation & 96 & be devastated & 379 \\
\hline 81 & relation & 94 & public sentiment & 379 \\
\hline 82 & event & 93 & public sentiment worsened & 379 \\
\hline
\end{tabular}


Table A1. Cont.

\begin{tabular}{|c|c|c|c|c|}
\hline \multicolumn{3}{|c|}{ Internet News (Governmental Sector) } & \multicolumn{2}{|c|}{ Blogs and Twitter (the Public Sphere) } \\
\hline Rank & Keyword & Frequency & Keyword & Frequency \\
\hline 83 & damage & 92 & site & 373 \\
\hline 84 & diffusion & 92 & Busan freight & 372 \\
\hline 85 & environment & 91 & occurrence & 359 \\
\hline 86 & reporter & 88 & Sewol ferry incident & 349 \\
\hline 87 & birds & 86 & Shin Seung & 340 \\
\hline 88 & words & 86 & Shin Seung-yong & 340 \\
\hline 89 & work & 85 & West Sea & 340 \\
\hline 90 & ship collision & 83 & Lee Soon-hyung & 336 \\
\hline 91 & Nakpo-dong & 83 & assistant inspector & 336 \\
\hline 92 & dismissal & 82 & $\begin{array}{l}\text { assistant inspector Lee } \\
\text { Soon-hyung }\end{array}$ & 335 \\
\hline 93 & Shindeok village & 82 & nose & 330 \\
\hline 94 & situation & 81 & diffusion & 322 \\
\hline 95 & responsibility & 80 & At the time & 317 \\
\hline 96 & pollution & 80 & Volunteer & 313 \\
\hline 97 & cause & 78 & Industrial accident & 305 \\
\hline 98 & Park Geun-Hye & 78 & Yoo Byeong-Eun's family & 304 \\
\hline 99 & blood & 77 & question thoroughly & 300 \\
\hline 100 & BP (British Petroleum) & 77 & Lee Kun-hee's family & 300 \\
\hline
\end{tabular}

\section{References}

1. Chang, S.E.; Stone, J.; Demes, K.; Piscitelli, M. Consequences of oil spills: A review and framework for informing planning. Ecol. Soc. 2014, 19, 26. [CrossRef]

2. Li, P.; Cai, Q.; Lin, W.; Chen, B.; Zhang, B. Offshore oil spill response practices and emerging challenges. Mar. Pollut. Bull. 2016, 110, 6-27. [CrossRef] [PubMed]

3. Knol, M.; Arbo, P. Oil spill response in the Arctic: Norwegian experiences and future perspectives. Mar. Policy 2014, 50, 171-177. [CrossRef]

4. Cheong, S.-M. Community adaptation to the Hebei-Spirit oil spill. Ecol. Soc. 2012, 17, 26. [CrossRef]

5. Adger, W.N.; Hughes, T.P.; Folke, C.; Carpenter, S.R.; Rockström, J. Social-ecological resilience to coastal disasters. Science 2005, 309, 1036-1039. [CrossRef]

6. Safford, T.G.; Ulrich, J.D.; Hamilton, L.C. Public perceptions of the response to the Deepwater Horizon oil spill: Personal experiences, information sources, and social context. J. Environ. Manag. 2012, 113, 31-39. [CrossRef]

7. Oil Budget Calculator Deepwater Horizon Technical Documentation; The Federal Interagency Solutions Group, Oil Budget Calculator Science and Engineering Team, 2010; pp. 38-40.

8. Brennan, K. A Stakeholder Analysis of the BP Oil Spill and the Compensation Mechanisms Used to Minimize Damage. Honors Thesis, University of South Florida, Tampa, FL, USA, 2013.

9. Gulf Coast Ecosystem Restoration Council. 2017. Available online: https://www.restorethegulf.gov (accessed on 23 March 2020).

10. Walker, A.H. Chapter 1 -Oil spills and risk perceptions. In Oil Spill Science and Technology, 2nd ed.; Fingas, M., Ed.; Gulf Professional Publishing: Boston, MA, USA, 2017; pp. 1-70. [CrossRef]

11. Simon-Friedt, B.R.; Howard, J.L.; Wilson, M.J.; Gauthe, D.; Bogen, D.; Nguyen, D.; Frahm, E.; Wickliffe, J.K. Louisiana residents' self-reported lack of information following the Deepwater Horizon oil spill: Effects on seafood consumption and risk perception. J. Environ. Manag. 2016, 180, 526-537. [CrossRef]

12. Easman, E.S.; Abernethy, K.E.; Godley, B.J. Assessing public awareness of marine environmental threats and conservation efforts. Mar. Policy 2018, 87, 234-240. [CrossRef]

13. Correa, T.; Hinsley, A.W.; de Zúñiga, H.G. Who interacts on the Web?: The intersection of users' personality and social media use. Comput. Hum. Behav. 2010, 26, 247-253. [CrossRef]

14. Bello-Orgaz, G.; Jung, J.J.; Camacho, D. Social big data: Recent achievements and new challenges. Inf. Fusion 2016, 28, 45-59. [CrossRef] 
15. Park, S. Characteristic of on-line newspapers as an alternative communication channel: A content-analysis of the Ohmynews. Korean J. Journal. Commun. Stud. 2001, 45, 117-155. (In Korean)

16. Song, T.M.; Song, J.Y. Prediction of Threat Recognition factors relating to North Korea with Application of Social Big Data. Natl. Secur. Strategy 2014, 14, 209-243. (In Korean)

17. Huh, M.-H.; Yoon, Y.-A.; Lee, Y.-G. Sample Distortion in Social Surveys and Effects of Weighting Adjustment: A Study of 18 Cases. Surv. Res. 2004, 5, 31-47. (In Korean)

18. Kang, N.J.; Baek, Y.M. Sampling Bias of Internet and Mobile Phone Survey: Correctional Sample Balancing through Propensity Score Weighting and Iterative Proportional Fitting Method. J. Commun. Res. 2004, 41, 43-78. (In Korean)

19. Noveck, B.S. Wiki Government: How Technology Can Make Government Better, Democracy Stronger, and Citizens More Powerful; Brookings Institution Press: Washington, DC, USA, 2009.

20. Lee, G.; Kwak, Y.H. An open government maturity model for social media-based public engagement. Gov. Inf. Q. 2012, 29, 492-503. [CrossRef]

21. Paul, M.J.; Sarker, A.; Brownstein, J.S.; Nikfarjam, A.; Scotch, M.; Smith, K.L.; Gonzalez, G. Social Media Mining for Public Health Monitoring and Surveillance. In Proceedings of the Pacific Symposium on Biocomputing, Big Island, HI, USA, 4-8 January 2016; pp. 468-479.

22. Kopec, A.N. Recent Incidents Attended by ITOPF and Lessons Learnt; IMO OPRC-HNS Technical Group Meeting: London, UK, 2014.

23. Statistics Korea. Marine Accident Statistics. Available online: http://www.index.go.kr/potal/main/ EachDtlPageDetail.do?idx_cd=1770 (accessed on 23 March 2020).

24. Ministry of Public Safety and Security (MPSS). Oil Pollution Statistics; MPSS: Sejong, Korea, 2017. (In Korean)

25. Ministry of Public Safety and Security (MPSS). Introduction of Marine Pollution Control Work; MPSS: Sejong, Korea, 2017. (In Korean)

26. Chung, M.G.; Kang, H.; Choi, S.-U. Assessment of coastal ecosystem services for conservation strategies in South Korea. PLoS ONE 2015, 10, e0133856. [CrossRef]

27. Statistics Korea. Census of Agriculture, Forestry and Fisheries; Statistics Korea: Daejeon, South Korea, 2010. (In Korean)

28. Statistics Korea. Changes in Coastal Wetland (Tidal Flat) Area. Available online: http://www.index.go.kr/ potal/main/EachDtlPageDetail.do?idx_cd=1275 (accessed on 7 February 2018).

29. Statistics Korea. Land Status 2017. Available online: http://www.index.go.kr/potal/main/EachDtlPageDetail. do?idx_cd=2728 (accessed on 7 February 2018).

30. Ministry of Oceans and Fisheries (MOF). National Comprehensive Survey of Marine Ecosystem-West Sea and Western South Sea; MOF: Sejong, South Korea, 2015. (In Korean)

31. Number of Mobile Phone Social Network Users in South Korea from 2013 to 2019. Available online: https: //www.statista.com/statistics/429726/number-of-mobile-social-network-users-south-korea (accessed on 23 March 2020).

32. Top 50 Countries by Smartphone Users and Penetration. Available online: https://newzoo.com/insights/ rankings/top-50-countries-by-smartphone-penetration-and-users (accessed on 8 February 2018).

33. Naver DataLab. Available online: http://datalab.naver.com/ca/step1.naver (accessed on 8 February 2018).

34. 2015 Search Engine Market Share by Country. Available online: http://returnonnow.com/internet-marketingresources/2015-search-engine-market-share-by-country (accessed on 8 February 2018).

35. Maum.ai. Available online: https://maum.ai/login/loginForm?lang=en (accessed on 8 May 2020).

36. Lim, H.; Rhee, J.W. The press' utilization of the government's press releases in Korea. Korean J. Journal. Commun. Stud. 2011, 55, 5-31. (In Korean)

37. BigKinds. Available online: https://www.kinds.or.kr/main.do (accessed on 8 March 2020).

38. Chowdhury, G.G. Natural language processing. Annu. Rev. Inform. Sci. 2003, 37, 51-89. [CrossRef]

39. Yoon, B.; Park, Y. A text-mining-based patent network: Analytical tool for high-technology trend. J. High Technol. Manag. Res. 2004, 15, 37-50. [CrossRef]

40. Perrow, C. Normal Accidents: Living with High Risk Technologies; Basic Books: New York, NY, USA, 1984.

41. Moldan, G.S.; Jackson, L.F.; McGibbon, S.; Van Der Westhuizen, J. Some aspects of the Castillo de Bellver oilspill. Mar. Pollut. Bull. 1985, 16, 97-102. [CrossRef]

42. Food and Agriculture Organization of the United Nations (FAO). FAO Yearbook of Fishery and Aquaculture Statistics; FAO: Rome, Italy, 2018; p. 9. 
43. Ministry of Land, Transport and Maritime Affairs (MLTM). A Study of Investigation of Impacts of Marine Pollution in Hebei Spirit Oil Pollution Accident and Restoration of Ecosystem; MLTM: Gwacheon, Korea, 2009. (In Korean)

44. Ministry of the Interior and Safety (MPSS). Volunteer Activity White Paper-Hebei Spirit Oil Spill Clean-up Activity; MPSS: Sejong, Korea, 2008. (In Korean)

45. Povlsen, E.; Hjorth, M. Technical Sub-Report 2: Environmental and Socioeconomic Vulnerability; BE AWARE, Bonn Agreement: London, UK, 2015; pp. 1-140.

46. Beyer, J.; Trannum, H.C.; Bakke, T.; Hodson, P.V.; Collier, T.K. Environmental effects of the Deepwater Horizon oil spill: A review. Mar. Pollut. Bull. 2016, 110, 28-51. [CrossRef]

47. Peterson, C.H.; Rice, S.D.; Short, J.W.; Esler, D.; Bodkin, J.L.; Ballachey, B.E.; Irons, D.B. Long-term ecosystem response to the Exxon Valdez Oil Spill. Science 2003, 302, 2082-2086. [CrossRef] [PubMed]

48. Aguilera, F.; Méndez, J.; Pásaro, E.; Laffon, B. Review on the effects of exposure to spilled oils on human health. J. Appl. Toxicol. 2010, 30, 291-301. [CrossRef] [PubMed]

49. Jeon, Y.-J.; Jang, B.-K.; Lee, I.-J.; Lee, J.-W.; Son, B.-S.; Cheong, H.-K.; Ha, M.; Choi, Y.-H.; Park, M.; Lee, S.-H.; et al. Impact of allergic diseases in elementary school students by the Hebei Spirit Oil Spill. Korean Public Health Res. 2016, 42, 57-68. (In Korean)

50. Picou, J.S.; Marshall, B.K.; Gill, D.A. Disaster, litigation, and the corrosive community. Soc. Forces 2004, 82, 1493-1522. [CrossRef]

51. Wu, Y.; Xie, L.; Huang, S.-L.; Li, P.; Yuan, Z.; Liu, W. Using social media to strengthen public awareness of wildlife conservation. Ocean Coast. Manag. 2018, 153, 76-83. [CrossRef]

52. Vann, A.; Meltz, R. The 2010 Deepwater Horizon Oil Spill: Natural Resource Damage Assessment under the Oil Pollution Act. Congressional Research Service 7-5700. 2013. Available online: https://biotech.law.lsu.edu/ blog/R41972.pdf (accessed on 29 August 2019).

53. French-McCay, D.; Beegle-Krause, C.J.; Rowe, J.; Rodriguez, W.; Schmidt Etkin, D. Oil spill risk assessment: Relative impact indices by oil type and location. In Proceedings of the 32 AMOP Technical Seminar on Environmental Contamination and Response, Vancouver, BC, Canada, 9-11 Jun 2009; Volume 2, p. 940.

54. Bolger, M.; Henry, S.H.; Carrington, C.D. Hazard and risk assessment of crude oil contaminants in subsistence seafood samples from Prince William Sound. In Proceedings of the Exxon Valdez Oil Spill Symposium, Anchorage, Alaska, USA, 2-5 February 1996; Volume 1996, pp. 837-843.

55. IPIECA-IOGP. Sensitivity Mapping for Oil spill Response: Good Practice Guidelines for Incident Management and Emergency Response Personnel; IOGP Report Number 477; IPIECA-IOGP: London, UK, 2015; pp. 1-34.

56. Petersen, J.; Michel, J.; Zengel, S.; White, M.; Lord, C.; Plank, C. Environmental Sensitivity Index Guidelines: Version 3.0; National Oceanic and Atmospheric Administration: Seattle, WA, USA, 2002; pp. 1-89.

57. Reich, D.A.; Balouskus, R.; McCay, D.F.; Fontenault, J.; Rowe, J.; Singer-Leavitt, Z.; Etkin, D.S.; Michel, J.; Nixon, Z.; Boring, C.; et al. Assessment of Marine Oil Spill Risk and Environmental Vulnerability for the State of Alaska; National Oceanic and Atmospheric Administration (NOAA): Seattle, WA, USA, 2014; pp. 1-102.

58. Murphy, D.; Gemmell, B.; Vaccari, L.; Li, C.; Bacosa, H.; Evans, M.; Gemmell, C.; Harvey, T.; Jalali, M.; Niepa, T.H. An in-depth survey of the oil spill literature since 1968: Long term trends and changes since Deepwater Horizon. Mar. Pollut. Bull. 2016, 113, 371-379. [CrossRef]

59. Chun, J.; Kang, B.; Kim, C.-K. Comparison of Korea and World Marine Oil Spill Studies: Long-term Trend Analysis Through in-depth Literature Review. J. Korean Soc. Mar. Environ. Energy 2018, 21, 30-39. [CrossRef]

60. Ministry of Public Safety and Security (MPSS). A Preemptive Study on Marine Pollution Response Caused by Environmental Changes such as International Ship Fuel Oil Regulation; Ministry of Public Safety and Security (MPSS): Sejong, Korea, 2017; pp. 1-112.

61. Chun, J.; Kim, C.-K.; Ha, C. A Study on the Improvement of National Marine Pollution Response Policy according to Change of Marine Pollution Incident Trend. J. Korean Soc. Mar. Environ. Energy 2019, 22, 57-65. [CrossRef]

62. Freudenburg, W.R.; Jones, T.R. Attitudes and stress in the presence of technological risk: A test of the Supreme Court hypothesis. Soc. Forces 1991, 69, 1143e68. [CrossRef]

63. Teal, J.M.; Howarth, R.W. Oil Spill Studies: A Review of Ecological Effects. Environ. Manag. 1984, 8, $27-44$. [CrossRef]

64. Fingas, M. The Basics of Oil Spill Cleanup; CRC Press: Boca Raton, FL, USA, 2013; pp. 1-286. [CrossRef] 
65. Tamis, J.E.; Jongbloed, R.H.; Karman, C.C.; Koops, W.; Murk, A.J. Rational application of chemicals in response to oil spills may reduce environmental damage. Integr. Environ. Assess. Manag. 2012, 8, 231-241. [CrossRef] [PubMed]

66. Huang, L.; Zhou, Y.; Han, Y.; Hammitt, J.K.; Bi, J.; Liu, Y. Effect of the Fukushima nuclear accident on the risk perception of residents near a nuclear power plant in China. Proc. Natl. Acad. Sci. USA 2013, 110, 19742-19747. [CrossRef] [PubMed]

67. McKinley, E.; Acott, T.; Yates, K.L. Marine social sciences: Looking towards a sustainable future. Environ. Sci. Policy 2020, 108, 85-92. [CrossRef]

(C) 2020 by the authors. Licensee MDPI, Basel, Switzerland. This article is an open access article distributed under the terms and conditions of the Creative Commons Attribution (CC BY) license (http://creativecommons.org/licenses/by/4.0/). 